\title{
Impact of Workers' Remittances on Poverty Index New Evidence from Jordan
}

\author{
Iyad A. Al-Nsour
}

\begin{abstract}
The workers' remittances is one of the most important sources of external cash inflows for many countries worldwide. This importance creates from its high added value in the economy reached $10 \%$ of GDP in Jordan's economy. So, this study aims to resolve the economic impact of the remittances by Jordanian workers on the poverty index during 2000-2018, the comparative effect of such remittances with economic growth, and the inequity in income distribution is manipulated. An econometric model is designed and the natural logarithm of variables in the research model is used. The dependent variable is the poverty index LP, while the independent variables are remittances of migrant workers REM, economic growth EG, and the inequality in income distribution IEQ using the ARDL approach. The study concludes that there are statistically significant effects of the remittances and economic growth on the poverty rate in Jordan in the long term with no significant, but the relationship between income inequality and the poverty index is not proved in the long and short terms. The study develops a set of recommendations contain key economic implications that ensure the better uses of cash inflow and improve their contribution to the national economy.
\end{abstract}

Index Terms - Economic Growth, Jordan, Migrants, Poverty, Remittances, Workers.

\section{INTRODUCTION}

The workers' remittances is one of the most important external resources of financial flows for most countries, and this refers to its valuable contribution comparing to other sources of funding such as external grants and subsidies and foreign direct investment [41]. These remittances seem also an influential element in full filling the life requirements of the large segment of migrants in the host countries, and improving the living standards and conditions of their families in the home countries [7]

The workers' remittances have grown rapidly and rising from $\$ 13$ billion in 2003 to $\$ 460$ billion in 2013 [64]. The actual estimates of remittances by professionals exceed the published figures, as well as the World Bank indicated that migrant workers remittances have steady growth in 2018 by $10 \%$ and reach $\$ 689$ billion worldwide. In 2019, the developing countries have the large proportion of remittances reach $76.6 \%$ (or $\$ 528$ billion), and it is growing by $3.7 \%$ with $\$ 715$ billion. In general, the total share of developing countries is $76.8 \%$ of worldwide remittances [64].

The geographical distribution of remittances indicates that India has the highest percentage by $13 \%$ of total migrant workers remittances worldwide with $\$ 70$ billion in 2014, compared to $\$ 80$ billion in 2018 and near to $2.7 \%$ of local
GDP. China has $\$ 67$ billion compared to $\$ 34$ billion for Mexico and the Philippines in 2018 [64]. At the level of Arab countries, Egypt has the first position with $\$ 20$ billion in 2018 and has $2.9 \%$ of total remittances worldwide. The share of Jordan economy has increased from $\$ 3$ billion in 2010 to 4.5 billion in 2018 [6].

Since 1980, the remittances of Jordanian workers have begun with a small number of migrant workers before reach 786 thousand workers in 2018. The figures show that $79.5 \%$ of Jordanians are working in the Arab Gulf countries and the Saudi labour market is the main employer of Jordanian workers by $61.4 \%$ of the Jordanian migrant workers [37]. Since that time, remittances have become one of the most important sources of funding for the Jordanian economy. Jordan has the tenth position among the developing countries with $\$ 4.5$ billion in 2018 and $10.7 \%$ of GDP. These remittances have extra effect comparing to the other sources of funding such as FDI and grants and subsides reach $\$ 960$ million and \$ 3.2 billion, respectively in 2018 [13].

The economic theory confirms that the efficiency of remittances in the home economy depends on their contribution to the GDP [44]. For example, according to 2013 figures the percentage of such remittances reach $42.1 \%$ of Tajikistan GDP, compared to $31.5 \%, 28.8 \%$ and $24.9 \%$ of GDP's in Kazakhstan, Nepal, and Moldova, respectively. The remittances have $17 \%$ and $6.3 \%$ of the Lebanese and Egyptian economies in 2013 respectively, and $10 \%$ in the Jordanian economy [64]. Therefore, we conclude that the relative importance of such remittances is affected increasingly in the developing countries, small and limited resources economies, and in the counties, which have economic problems [66]. The differences in the research results that examined the impact of migrant workers' remittances on the home economies refers to last conditions.

\section{LITERATURE REVIEW}

The impact of workers' remittances is seen by its increasing role in the capital formulation in the home countries of migrants [10]. The transferred amounts improve the ability of financial institutions through expanding the credit, meeting the financial needs of the household, and finance other economic activities [66]. Workers' remittances may go to the saving account in the home banks, and thus reduce the volatility in the business cycle [66]. The remittances play a key role in improving the financial development indicators and parameters of the economy [55]. 
The workers' remittances is a low-cost source for foreign currency, and it is among the most important sources that enhancing the balance of the foreign reserves in the home countries, meeting the financial needs and providing the requirements of investment [48]. The remittances improving the fluency of capital and the investment rate in human capital, increasing exports, enhancing political stability and alleviating poverty, and in finally increasing the growth rate and GDP in the home countries [3].

The workers' remittances has power in income distribution in the local economy, because these amounts of money are oriented towards family members of the expatriates in the home country and it will be used for resolving the financial problems and financing the consumption needs and shortterm expenditures [66]. This confirms its effective role in poverty alleviation as well as improve the human capital due to spending on education and training, and in the result this increase the total productivity of labor in the home economy [10].

The remittances of Jordanian workers have a greater impact on the poor families of migrant workers areas than others, so the international institutions are concerned with local communities by social initiatives and programs to better uses of the remittances in productive and sustainable projects [38].

This will enhance the financial leverage and the financial independence of targeted families [38].The International Monetary Fund has shown that migrant remittances improve the economic climate in the home country even in times of economic depression [35]., it is an effective tool to cut the seasonal fluctuations during the business cycle, developing the capital markets at low costs, and improve the investment rates in the real estates and fixed assets [36].

Pant (2008) emphasizes that remittances are a major simulator of demand on goods and services especially in real estate and other assets. Migrant workers also give different forms of financing such as financial, social, cultural, political, and economic fields. There is a clear tag about the impact of remittances on the growth rate, poverty, and economic development in the home countries [51].

The literature argues that remittances may decrease the desire of work among poor families in the home country, and discourages free time, so the level of income may be reduced [49]. Other studies have shown that the negative impact of remittances is increased in the case of the unproductive projects and bad investment decisions [11].

In the long-term, the workers' remittances are a reason for drain brain of the qualified and well-trained persons, and with no thinking for travel back for their countries in the long run. The rapid and continuous migration will cut the social development and decrease the level of the qualified workforce in the home economy. As a result, the home countries need a lot of money and time to compensate for the losses in the labor force [45].

The massive dependence on workers' remittances will reduce the country ability in finding alternative financial resources [40]. The exchange rate of the local currency is devalued as well as the competitiveness of national exports will reduced [43]. The inflation rate will increase, and this requires newly issued money in order to the economic stability and the exchange rate, meanwhile the production costs and selling prices are higher than imports costs [50]. The workers' remittances have a negative impact on income distribution in the home country, and the differences between the poor families migrant and non- migrant workers are significant [1].

Finally, the host countries of workers can use the workers' remittances to pull the highly qualified, well-trained and young workers; and this may make a negative socio economic loses, and shortage in human development output, but the positive overview concludes that migration is an effective solution to cut the unemployment rates and create new job vacancies to the people in the home country [46].

The main hypothesis in this study can be formulated as follow:

The worker's remittances have a positive impact on reducing poverty rates in Jordan during 2000-2018.

\section{THE EMPIRICAL STUDY}

\section{A. Study Data}

The workers' remittances increased from $\$ 450$ million in 1990 to $\$ 1.85$ billion in 2000 with a high growth rate of $312 \%$ during this period. The time period 2001-2004 has a slowdown in the remittances. In 2002 the remittances of Jordanians have the lowest amount reach $\$ 2.02$ billion, and this decline refers to the second gulf war, which caused the return of a large part of Jordanian workers in the gulf area [13].The period that comes after 2002 has a steady increase in the remittances reach $\$ 3.5$ billion in 2008 before declining to $\$ 3.46$ billion in 2009 , which refers to the constitutes of the world financial crisis. Such negative was a motive for the administrative, structural, and financial reforms in the companies, the effect is fired a number of Jordanian workers in such companies [13].

The workers' remittances have a slow growth rate in 2002 (\$3.62 billion), but after 2012 it has steady growth and arrived at the peak point in 2014 by $\$ 6.37$ billion. In 2018 the remittances were to $\$ 4.47$ billion, due to the demobilization a part of Jordanian labor Expatriate in some Arab markets. Accordingly, we note that the remittances of Jordanian workers are going parallel with the global political and economic conditions. The economic openness, labor force globalization, joint interests, and COVID -19 are the coming reasons for the changes in the number of Jordanian workers, so the variations in the amount of remittances in the coming years will be significant than before.

In other words, the workers' remittances to GDP percentage was decreased from the peak point in 1997 reach $25.1 \%$ into $20 \%$ in 2004 , and by $13.7 \%$ in 2010 , and $14.3 \%$ in 2015 before the big rescission to up $10.6 \%$. In 2018, the percentage of remittances to GDP as same as in 1990 $(10.79 \%)$. The changes in the percentage of remittances to GDP is functioning in the expansion in the economic activity from $\$ 8.46$ billion in 2000 to $\$ 42.2$ billion in 2018 . The remittances have grown during $2004-2014$ by $63.1 \%$ because of the large increments in the migrant Jordanian workers, and it must be noted that $80 \%$ of such remittances come from the Arab Gulf countries [37].

In summary, according to literature, it is found that $67.9 \%$ of expatriate workers transfer their money to home banks in their savings accounts, and the average annual income of the expatriate worker is J.D 38.7 thousand, while the average 
transferable amount reach J.D 13.7 thousand and $35 \%$ of the annual income. The data show that $36.7 \%$ of migrant workers use a mix of channels for money transfer. The survey shows that a part of the remittances don't use the official banking channels, and $64.4 \%$ of the migrant workers transfer their money to their personal banking accounts in the home country [37].

\section{B. Study Model}

The main hypothesis in this study try to revolve the impact remittances of expatriate workers on the poverty rate in Jordan, and in order to achieve the study objectives, the following model is used:

$$
\left.L P_{\mathrm{t}}=\propto+B_{1} L R G D P_{t}+B_{2} L I E Q+B_{3} L R E M_{t}\right)
$$

Whereas the LP is the dependent variable and measured by the poverty index, while the independent variables are the real GDP, IEQ, and REM which represents the economic growth, inequality in income distribution, and workers' remittances. The research model is used in the time series from 2000 to 2018. The missed data is calculated by the researcher.

\section{Study Methodology}

The ARDL approach in the co-integration test is distinguished by applicability regardless the variables used are integrated from degrees (0) or (1). This integration from different ranks means applying the integration if the rank is unknown and different for all study variables. This approach is acceptable in the small samples, in contrast to most traditional cointegration tests require large samples for efficient results. The ARDL approach can estimate the short and long terms relationships at the same time using one equation instead of two separate equations [56].

\section{Testing The Research Data}

\section{A. Structural Stationary of ARDL}

The stationary test using the Unit Root Test for Dickey Filler. This test aims to resolve the stationary of research variables, and it must be noted that the stationary test is not a necessary condition for the ARDL approach but is sufficient for more accurate and fitness in the model. In the second difference stationary (I (2)), the model may not be accurate compared with the stationary in the first degree.

Table 1 shows the results of the Augmented Dickey Filler test ADF and the study variables have no stationary at the first the difference because the calculated values are less than the tabulated at all significant levels. After calculating the first difference it is found that the study is stationary at the significance levels $5 \%$ and $10 \%$.

TABLE 1: THE StRUCtURAL StaTIONARY TEST

\begin{tabular}{ccccccc}
\hline \multirow{2}{*}{ Variable } & \multicolumn{3}{c}{ Level } & \multicolumn{3}{c}{ First Difference } \\
\cline { 2 - 7 } & ADF Statistics & Prob. & Result & ADF Statistics & Prob. & Result \\
\hline LP & -2.783165 & 0.22 & Nonstationary & -5.758251 & 0.0013 & Stationary \\
\hline RGDP & -2.881409 & 0.1929 & Nonstationary & -2.783535 & 0.2208 & Nonstationary \\
\hline REM & -4.865307 & 0.0080 & Stationary & -9.020179 & 0.0000 & Stationary \\
\hline IEQ & -2.919055 & 0.1811 & Nonstationary & -3.518342 & 0.0694 & Nonstationary \\
\hline
\end{tabular}

Pesaran has shown that the UECM formula in the ARDL approach means the structural stationery of estimators in the short and long run. UECM aims to resolve if the data are free of structural changes [54].

The Cumulative Sum of Recursive Residual CUSUM and the Cumulative Sum of Square Recursive Residual CUSUMSQ are used, and according to the statistical rule, the estimators have structural stationery in the UECM formula if the tow figures of CUSUM and CUSUMSQ located within the critical boundaries at the 5\% significance level and the coefficients will be non-stationary if the figures move out-ofboundaries at this level.

According to the following figures, the ARDL estimators have structural stationary during the period 2000-2018, and this means that there is stability among the study variables and consistency in the error correction in the short and long terms. The two figures are within the critical boundaries $5 \%$ [56].

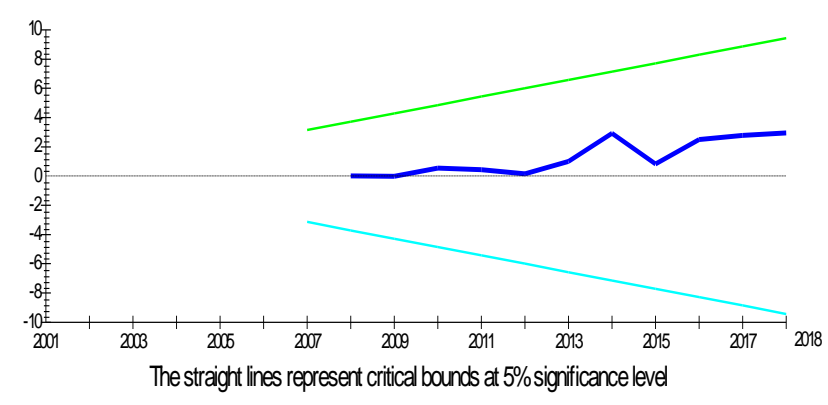

Fig. 1. Plot of Cumulative Sum of Recursive Residuals.

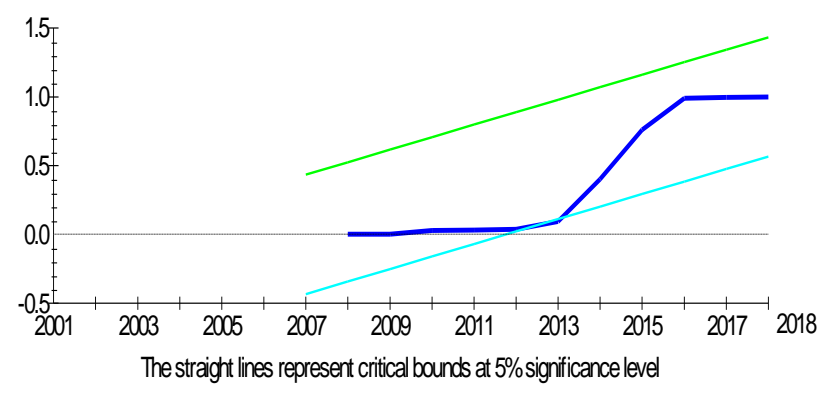

Fig. 2. Plot of Cumulative Sum of Squares of Recursive Residuals.

\section{B. Diagnostic Tests}

The degree of fitness in the model means the model is free from econometric problems. For this purpose, the diagnostic 
tests represented in Lagrange Multiplier tests are conducted in Table 2.

The serial correlation test among random errors - BreuschGodfrey Serial Correlation LM Test- says that the F value is 8.1858 at the statistical significance level 0.015 (The corresponding $2 \mathrm{x}$ value equals 7.679 at the significance level 0.006). According to statistical rule, the null hypothesis is rejected, and there is no serial correlation in the regressed equation. Ramsey Test aims to determine the model fitness, and the statistical results decide that the null hypothesis is accepted, and the model has the indetermination problem according to the statistical significance level (0.843).

Jarque-Bera the test aims to determine the normality in the residuals of regression. The results indicate that the null hypothesis is accepted and the residuals of the regression the equation is normally distributed. The $\mathrm{X}^{2}$ is 0.1678 at the significance level (0.92), so this model has no abnormal distribution of the residuals in the regression equation.

Finally, an Autoregressive Conditional Heteroscedasticity Test (ARCH) aims to resolve the error limit variance hypothesis, and it is found that the ARCH value is 59.457 at the level of statistical significance (0.00), and this means that limit variance of Random error in the estimated model is stationary.

\begin{tabular}{ccc}
\multicolumn{3}{c}{ TABLE 2: DiagonstiC TESTS } \\
\hline$*$ Test Statistics & $*$ LM Version & $*$ F Version \\
\hline \multirow{2}{*}{ A:Serial Correlation } & $*$ CHSQ $(1)=7.6798[.006]$ & $\begin{array}{c}\mathrm{F}(1,11)= \\
8.1858[.015]\end{array}$ \\
\hline \multirow{2}{*}{ B:Functional Form } & $*$ CHSQ $(1)=0.066914[.796]$ & $\begin{array}{c}\mathrm{F}(1,11)= \\
0.041044[.843]\end{array}$ \\
\hline C:Normality & $*$ CHSQ $(2)=0.16782[.920]$ & Not applicable \\
\hline D:Heteroscedasticity & $*$ CHSQ $(1)=14.1833[.000]$ & $\mathrm{F}(1,16)=$ \\
& & $59.4574[.000]$ \\
\hline
\end{tabular}

\section{THE EMPIRICAL RESULTS}

\section{A. Regression of Co- integration Using ARDL}

The ARDL is the most proper approach to resolve the cointegration among the model variables, so the time lag of the first difference in the model should be determined. The results show that there is one year lag for the real GDP and the remittances of migrant workers, while there is no time lag of the inequality in income distribution. According to the Schwarz Bayesian Criterion SBC, the model becomes as $(1,0,1,1,1)$ in Table 3 [34].

The results of the regression equation show that there is a statistically significant level of model fitness according to the determination coefficient $\mathrm{R}^{2}(0.779)$. This means that the model used explains $77.9 \%$ of the variations in the poverty index, so the relationship between the dependent and explanatory variables is actual. This significance level of the F test (0.001) is less than 5\%. According to statistical rule, there no negative serial correlation of residuals using the DW statistic. The hypothesis decides that there is no serial correlation of residuals in the regressed equation is accepted.

To ensure the existence of the co-integration among the model variables, the boundaries test is used for the cointegration in Table 4, and it is found that the value of $\mathrm{F}$ is equal to 4.5301 and the statistical significance (0.021) which is less than 0.05. This means that the hypothesis says that there is a relationship of co-integration among model variables is accepted. This integration implies a long-term relationship among these variables.

TABLE 3: Autoregressive Distributed LAG Estimates: ARDL $(0,1,0,1)$ BASED ON SBC

\begin{tabular}{|c|c|c|c|}
\hline DV is LP & \multicolumn{3}{|c|}{18 observations used for estimation from $2000-2018$} \\
\hline Regressor & Coefficient & SE & T-Ratio[Prob] \\
\hline RGDP & -22.4354 & 8.1349 & $-2.7579[0.017]$ \\
\hline RGDP(-1) & 14.2001 & 7.7989 & $1.8208[0.094]$ \\
\hline IEQ & 0.067865 & 0.18256 & $0.37175[0.717]$ \\
\hline REM & 5.3454 & 3.7377 & $1.4302[0.178]$ \\
\hline $\operatorname{REM}(-1)$ & 11.5624 & 4,1306 & $2.7992[0.016]$ \\
\hline $\mathrm{C}$ & -37.8073 & 15,954 & $-2.3697[0.035]$ \\
\hline \multicolumn{3}{|c|}{$\begin{array}{l}\text { R-Squared }=0.7797 \quad \text { R-B } \\
\text { S.E. of Regression }=1.5006 \quad \text { F-stat. } \\
\text { Mean of DV }=15.3167 \\
\text { Residual Sum of Squares }=27.0232 \\
\text { Equation Log-likelihood }=-29.1978 \\
\text { Akaike Info. Criterion }=-35.1978 \\
\text { Schwarz Bayesian Criterion }=-37.8689\end{array}$} & $\begin{array}{r}\mathrm{F}(5,12)=8.4978[.001] \\
\text { S.D.of DV }=2.6866 \\
\text { DW-statistic }=3.2208\end{array}$ \\
\hline \multicolumn{3}{|c|}{ R Co -Integration } & $01[.021]$ \\
\hline
\end{tabular}

TABLE 4: EsTIMATED LONG RUN COEFFICIENTS USING ARDL APPROACH

\begin{tabular}{cccc}
\hline DV is LP & \multicolumn{3}{c}{18 observations used for estimation from 2000 - 2018 } \\
\hline Regressor & Coefficient & SE & T-Ratio[Prob] \\
\hline RGDP & --8.2353 & 2.3805 & $-3.4594[.005]$ \\
\hline IEQ & 0.067865 & 0.18256 & $0.37175[.717]$ \\
\hline REM & -16.9078 & 3.7906 & $-4.4604[.001]$ \\
\hline C & -37.8073 & 15.9544 & $--2.3697[.035]$ \\
\hline
\end{tabular}

Table 4 shows the long-term estimators using ARDL, and there is a significant effect of remittances on the poverty index during 2000-2018. The increase of remittances by J.D one billion means the reducing the poverty index by $16.9 \%$, and this result is consistent with literature that confirm this relationship. The workers' remittances to home countries play a key role in economic stability regardless of the economic situation in the host countries [65]. The effectiveness of remittances in reducing the poverty index in the poor areas is proved. Such remittances improve the macroeconomic indicators [15].

Uruci and Gedeshi confirm that $69.7 \%$ of the amounts transferred have oriented to the basic needs of poor people [15]. Adams and Page show that there is a significant statistical effect of remittances on the poverty index for 71 developing countries, and any increases in remittances to GDP by $10 \%$, the poor index will be reduced by $1.6 \%$ [3] The World Bank in 2004 indicates that the workers' remittances are significantly increased in the developing countries [35]; meanwhile the foreign direct investment FDI and grants are fluctuated according to the world economic events at the late nineties [31].

Campos and Palomo have shown that reduction in the poverty rate by $4.2 \%$ in El Salvador was decreased the income inequality from 0.55 to 0.53 [30]. Adams (2005) have agreed that the poverty gap will be decreased by $19.8 \%$ if the workers' remittances within the total income of families in Guatemala [2]. López et al. says that migrant remittances have a negative significant effect on poverty in Mexico [43]. 
Gustafsson and Makonnen found that remittances have affected poverty and welfare in rural and urban areas in Lesotho for 7680 households families during 1986-1987 [27], and it noticed that $35 \%$ of the family income comes from remittances and the zero point of remittance means a decrease in the consumption by $32 \%$, and increase by $26 \%$ and $52 \%$ in the poverty index poverty gap [9].

Another a study by Taylor et al on 1782 Mexican household families in 2003 , it is found that any increases in workers' remittances by $10 \%$ have reduced the poor people and the poverty gap by 0.77 and 0.53 , respectively [60]. Finally, Banga and Sahu have analyzed the impact of workers' remittances on development indicators in 77 Asian countries, and found that the most significant results were in the countries that remittances to GDP percentage more than $5 \%$ and the poverty clearly decreased [9], and Ali \& Asif decided the three key elements that support the economic growth and poverty rate in India, which are the contribution of such remittances in economic decision-making, political stability and caring with the poor farmers [5].

On the other hand, our study concludes the significant negative correlation between the economic growth and poverty index in Jordan during 2000-2018. The increase in the GDP by J.D one billion will cut the poverty rate by $8.2 \%$, and this results is consistent with the literature support the importance of poverty for economic decision makers, the effect on the standard of living and social life [16].

The study of Deaton and Kozel confirms the importance of economic growth in reducing poverty in India, then the better economic growth will be increased [19]. Banerjee et al study justifies that growth in agricultural income reduces the poverty in India during the periods 1999-2000 and 2005-2006 [8]. Datt et al adds that economic growth is a key tool for poverty alleviation during 1957 - 2012 [18], and Fosu confirms this results in a number of African countries [22].Whereas, Gangas have agreed that lower poverty is a motive for economic growth, and the higher rates of unemployment will kill the prosperity and cause the poverty, especially among the low-skilled people [25].

Meanwhile, the study of Ravallion is one of the few studies provides an important details about how poverty effects economic growth and he says that the poverty cause lower rates of economic growth; and the poor people become the most vulnerable group to malnutrition [58]. Hanson et al studied the human brain for a sample of American children between 5 months and 4 years. They showed that the gray area for poor children is less than rich children. This area is responsible for processing information and life routine decisions. They conclude that the less space of gray leads to difficulties in the learning, low human capital formation, and low opportunities in better schools [28], as well as lack of higher education for parents, and lower fertility rates [59]

The correlation between the national income and poverty runs in a vicious circle; studies show that an increases in the extreme poverty by $10 \%$, the income will reduced by $0.89 \%$ to $2.15 \%$, so poverty constitutes are harmful to economic development, kill the growth rate and the welfare of society [24].Other studies have shown that economic growth is a key motive for reducing the poverty rates, and this is will make the economic policies stable, better investment in the agricultural sector, developing the infrastructure and good corporate governance [33].

Hassan examined the relationship between unemployment (measured by poverty), and GDP (measured by economic growth), and he a weak relationship, but the positive relationship between them is proved, and the economic growth has no role in creating new jobs in the economy for poor people [29].To confirm this result, the study in 2016 show that economic growth has no effect on poverty in Nigeria, and the high GDP and per capita income are factors have no effect on the poverty rate, so the corruption and poor educational and health policies in the country lead to such result.

Finally, according to the Gini coefficient as a measure of inequality in income distribution IEQ, our study concludes that Gini coefficient has low impact on poverty alleviation in the long run, and this result agrees with Partridge's study that the income inequality in the middle class is no effective tool on poverty in the long run in the United States [52], and the relationship in the short term not clear [53].Our study says that the strong middle class is the key pillar of the economy and the growth engine, because of its contribution in the education sector and the tax system. Forbes also show results that confirm the positive relationships among inequality in income distribution and economic growth in the short and long terms [20]. Li and Zo emphasized this relationship [42], and Frank adds that there is a positive relationship between economic growth and inequality in income distribution during 1945-2004 in the United States [23]. In details, the increases in the poverty through the income distribution is lower than increases in the poverty through the economic growth.

On the other hand, poverty kill the economic growth and the changes in income distribution reduces the long run growth [61], and Kwasi have added that the weak relationship between economic growth and poverty [39]. Hull said that the growth in any economic sectors have no significant contribution on poverty [32]. Adam explained that the growth elasticity of GDP to poverty differs from country to another, and this depends on the inequality in income distribution [4] so Fosu believed that this difference has a negative impact on the economic growth [22], and therefore the poverty will increase [58]. Finally, the Breunig and Majeed have reinforced the negative impact of inequality in income distribution in the countries where poverty is increased [12].

\section{B. Error Corrective Model Using ARDL}

After estimating the long-run relationship in the cointegration model, we evaluate the ECM model which explains the dynamic relationship between the dependent and explanatory (independent) variables in the short run. Based on the estimation results $(1,0,1,1,1)$ and according to the SBC test, the short-run estimators (elasticities) show in table 5. All explanatory variables: economic growth, remittances of migrant workers, inequality in income distribution have no short run significant effect on the poverty index in Jordan.

First of all, remittances of migrant workers have an impact on the poverty rate in the long run, while there is no effect in the short run. The researcher believes that the cumulative effect of remittances on the poverty among the poor people is clearer in the long run, so improving the uses of remittances is more efficient in the long-run, and it may become a part of 
sustainable development and productive projects. While the remittances still have no effect in the short run, because it is consumed in non- basic needs, regular purchase, paying the obligations, and losses in a bad investment.

The economic growth has no statistical significant effect in the short run, and this variable is not able to cut the poverty rate in Jordan during the studied period, and the researcher notes that economic growth in the short run is based on a set of financial considerations that focusing on the taxation system in the economy. Of course, this policy has reduced the disposable income, and increased the costs of new job vacancies.

Therefore, economic growth has no priorities and considerations of the balanced growth among all segments of society. Also, there are bad results of economic reform, the public debt and the budget deficit are peaked, and such reform priority focus on the short run objectives such as financing the current expenditures and public debt service. The economic priority should focus on the large scale industries. The economic growth rate has increased rapidly in the period $2004-2008$ by $8 \%$, mostly refers to the service sector with no significant signs for the agricultural and industrial sectors. The large part of such growth refers to the privatization policy of the government during this time, and the privatization returns reach J.D 1.8 billion in 2008. The main privatized projects are cement, potash and phosphate, telecommunications, and electricity. The government plays the regulator role in managing the economy. Most of the economic reform programs aims at financial reform through the taxation system [47]. Maximizing the tax revenues and imposed new tax burdens on the tax payers especially the poor people. The economy of Jordan is small, limited and lack of resources. The free market mechanism is the economic model.

TABLE 5: ECM RESULTS USING ARDL

\begin{tabular}{|c|c|c|c|}
\hline $\mathrm{DV}$ is LP & \multicolumn{3}{|c|}{18 observations used for estimation from $2000-2018$} \\
\hline Regressor & Coefficient & SE & T-Ratio[Prob] \\
\hline dRGDP & -12.0514 & 14.1734 & $-0.85029[0.411]$ \\
\hline dGNI & -13.0142 & 11.9234 & $-1.0915[0.295]$ \\
\hline dREM & 3.4011 & 4.1102 & $0.82747[0.423]$ \\
\hline $\mathrm{dC}$ & -6.1052 & 28.6934 & $-0.21278[0.835]$ \\
\hline ecm(-1) & -1.2368 & 23.466 & $-5.2706[0.000]$ \\
\hline \multicolumn{3}{|c|}{$\begin{array}{l}\text { Additional Temporary Variables Created: } \\
\text { dRGDP = RGDP-RGDP }(-1) \\
\text { dGNI = GNI-GNI }(-1) \\
\text { dREM = REM-REM }(-1) \\
\text { dC = C-C }(-1) \\
\text { ecm }=\text { LP }+0.68432 * \text { RGDP }+10.5226 * \text { GNI } \\
4.9364 * \mathrm{C}\end{array}$} & $-13.9356 * \mathrm{REM}+$ \\
\hline $\begin{array}{l}\text { R-Squared } \\
\text { S.E. of Reg } \\
\text { Mean of D } \\
\text { Residual St } \\
\text { Equation L } \\
\text { Akaike Info } \\
\text { Schwarz Bc }\end{array}$ & $\begin{array}{l}0.79835 \\
\text { sion }=1.4708 \\
=0.17222 \\
\text { of Squares }= \\
\text { likelihood }= \\
\text { riterion }=-35 \\
\text { sian Criterion }\end{array}$ & $\begin{array}{l}\text { R-Bar-Squar } \\
\text { F-stat. F(4, } \\
\text { S.D.of DV } \\
45 \\
526 \\
6 \\
8.1689\end{array}$ & $\begin{array}{l}\text { ed }=0.68835 \\
13)=10.8872[.000] \\
=2.6346\end{array}$ \\
\hline
\end{tabular}

The government liberalized the basic goods required for most of population such as electricity, water, oil products, bread ... etc. On the other hand, the long-run economic growth offers an opportunity for poor people in education and health particularly; and this cut poverty. Finally, our study finds that the GINI coefficient which measure the inequality in income distribution IEQ is not able to reduce the poverty in the short and long terms. The relationship between GINI and IEQ is not clear. We conclude that there is declined in the middle class in the economy, the service sector based economic growth, and the poverty rates reach $15.7 \%$ of the total Jordanians.

The results of the lag coefficient of ECM shows that there is a quick back of economic growth to normal equilibrium in the long run, and the time period in the inequilibrium in the time (t-1) is (1.23-). This factor of adjustment is considered a relatively high. This means that the short long-run variation in the poverty from the long-run equilibrium in the time (t-1), the adjustment factor is $123 \%$. The back time to equilibrium point in the time $\mathrm{t}$ needs less than 2 years. The statistical significant of error limit coefficient (0.00) is less than $5 \%$, which means that the co-integration among independent and dependent variables (poverty rate) is proved.

The researcher believes that relative poverty is the most widespread in Jordan reach 1.069 million of Jordanians or $15.7 \%$ of total population in 2019.Therefore any official policies focus on the poor people, this percentage may be reduced in the short run directly. According to literature, poverty means insufficient resources to meet the basic needs of poor people ant there is many types of that such as lack of income, insufficient food, poor access to education, lack of productive resources for sustainable livelihoods, malnutrition, poor health, and homelessness [33].

Here, the study confirms that extreme poverty is the most influential type of social and economic safety and requires long-run strategies. The Department of Statistics decides that the number of poor people within this category reach 8 thousand Jordanians in 2019.

\section{CONCLUSION}

Poverty is a lack of income to meet the physiological needs such as air, food, clothing, shelter, and other reproduction resources. However, poverty is a deeper concept and not only a lack of income or basic facilities, but also a lack of development within the country. The World Bank (2002) indicated that poverty includes many forms starting from hunger, lack of shelter, disease and the inability to visit a doctor, go to school, unemployment, and fear from the future. The poor people have a weak participation in decisionmaking in the social, economic, and cultural issues, and they have a weak engagement in the society as a whole. The extreme poverty, insufficient resources and poor quality of life are common characteristics of the poor people in general.

Studies have shown that workers' remittances play an effective role to recoup the poverty constitutes. $69.7 \%$ of the transferred amounts went to meet the physiological needs of the poor families. The results confirm that the positive impact of migrants' remittances on poverty, and the importance of such remittances rapidly increased in the economic crises, comparing to the foreign direct investment and international grants. The most common evidence that migrants' remittances have an effectively influenced on poverty in the rural and urban areas. The poverty gap becomes clear and the economic importance of migrants' remittances significantly 
increased in the countries that recorded more than $5 \%$ of remittances to GDP.

It is found that the economic growth may reduce the poverty rate by $8.2 \%$ because of the significant impact of economic growth and on a large part of the life of poor people. It is also find that sectoral growth reduces the poverty rate as well. Studies add that the significant negative relationship between the economic growth and poverty is proved. The poor people are the most vulnerable to malnutrition, unemployment, illiteracy, and a low fertility rate. Therefore, the poverty index determines by economic development, and a high rate of poverty means curbing economic growth and reducing the welfare of society. There are many requirements for sustained economic growth and best allocation of development gains such as investment in the agricultural sector, developing infrastructure, and good corporate governance. While corruption, poor economic planning, and bad education and health will deepen poverty in the long run.

The current study also shows that the relationship between inequality in income distribution and poverty is not clear. The middle class rapidly decreased towards the low poor class, the taxation policies, the economic failure, bad distribution of income, and the wealth concentration in a small segment of the population. The income inequality increases the poverty while economic growth reduces it. All of last results mean that the high inequality in income distribution generate a little economic growth in the long run, and this evidence is clearly shown in the Jordan economy. The economic growth decreased to less than $3 \%$ after 2010 , so the unemployment rate reach $19.2 \%$ in 2019 , and overall economic productivity decreased significantly.

Finally, our study shows not only that the effect of economic growth is less than remittances on poverty in the long run, but also there is no effect of inequality in income distribution. The remittances of migrants are an equilibrium tool in the economy, so the poverty decreased by $2.36 \%$ during a studied period refers to the workers' remittances.

\section{REFERENCES}

[1] Adam, Richard H., "Remittances, investment and rural assets accumulation in Pakistan", Economic Development and Cultural Change, vol .47, pp. 155-173. 1998

[2] Adams, Jr., Richard., "Remittances, Household Expenditure and Investment in Guatemala", Policy Research Working Paper 3532 World Bank, Washington, DC, 2005.

[3] Adams, R and J. Page, "Do International Migration and Remittances Reduce Poverty in Developing Countries?", World Development, vol.33, no. 10 , pp. 1645-69, 2005.

[4] Adams, R. H., "Economic growth, inequality and poverty: Estimating the growth elasticity of poverty", World Development, vol. 32, no. 12, 1989-2014, 2004.

[5] Ali, F., and Asif , M., "Assessing The Impact of Economic Growth on Inequaluity in India", EPRA International Journal of Economic and Business Review, vol.8 , no. 6, pp. 5-8, 2020

[6] Arab Monetary Fund, annual statistical data, various years, Abu Dhabi.

[7] Azam, M and Khan A, "Workers' Remittances and Economic Growth: Evidence from Azerbaijan and Armenia", Global Journal of Human Social Science, vol. 11, no. 1, 2011.

[8] Banerjee, A.N., Banik, N., Mukhopadhyay, J.P, "The dynamics of income growth and poverty: evidence from districts in India", Dev. PolicyRev. Vol. 33, no. 3, pp. 293-312, 2015.

[9] Banga, R., and Sahu, P. (2020). Impact of Remittances on Poverty in Developing Countries. [Online]. Available https://www.researchgate.net/publication/254412418
[10] Barajas, A., Chami, R., Fullenkamp, C., Gapen, M., Montiel, P, "Do workers' remittancespromote economic growth? ", IMF Working Paper WP/09/153, 2009.

[11] Bayar, Yilmaz, "Impact of Remittances on the Economic Growth in the Transitional Economies of the European Union", economic insights, vol. IV, no. XVII, p.3, 2015.

[12] Breunig, R. V., and Majeed, O., "Inequality or Poverty: Which is Bad for Growth?" CAMA Working Paper, no, 43, 2016.

[13] Chami. R; Barajas. A: Cosimano. T: Fullenkamp .C: Gapen. M, and Montiel.P, "Macroeconomic Consequences of Remittances", Occasional Paper, IMF, Washington DC, Occasional Paper, no.259, 2008.

[14] Chami, R., Connel, F., and Samir J., "Are Immigrant Remittance Flows a Source of Capital for Development? "IMF Staff Papers, vol.52, no.1, 2005.

[15] Chen, S., Ravallion, M., "More relatively-poor people in a less absolutely-poor world", Rev. Income Wealth, vol.59, no. 1, pp. 1-28, 2013.

[16] Cohen, J., "Remittance Outcomes and Migration: Theoretical Contents, Real Opportunities", Studies in Comparative International Development, vol. 40, no. 1, pp. 88-112, 2005.

[17] Datt, G., Ravallion, M., and Murgai, R.m, (2016) "Growth, Urbanization and Poverty Reduction in India", NBER Working Paper Series, no. 21983. [Online]. Available http://www.nber.org/papers/w21983

[18] Deaton, A., Kozel, V., "Data and dogma: the great Indian poverty debate”, World Bank Res. Obs, vol. 20 no. 2, pp. 177-199, 2016.

[19] Forbes, K. "A Reassessment of the Relationship between Inequality and Growth", American Economic Review, vol. 90, pp. 869-887, 2000.

[20] Fosu, A.K., "Growth, inequality, and poverty in sub-Saharan Africa recent progress in a global context", Oxford Dev. Stud, vol. 43, no. 1 , pp. 44-59, 2015.

[21] Fosu, A.K., "Inequality and the Impact of Growth on Poverty: Comparative Evidence for SubSaharan Africa", Journal of Development Studies, vol. 45, no. 5, pp. 726-745, 2009

[22] Frank, M. W., "Income inequality, human capital, and income growth: Evidence from a State-Level VAR analysis", Atlantic Economic Journal, vol. 37, pp. 173-185, 2009.

[23] Galster, G.C., Cutsinger, J., Malega, R., "The costs of concentrated poverty: neighborhood property markets and the dynamics of decline", In:Retsinas, N., Belsky, E. (Eds.), Revisiting Rental Housing. Brookings Institution Press, Washington, D.C, 2008, pp. 93-113.

[24] Gangas, S. "Relationship between Economic Growth and Poverty Reduction in Nigeria", Pyrex Journal of Business and Finance Management Research, vol. 3 , no.2 ,pp. 34-56, 2017

[25] Giuliano, P., and Ruiz-Arranz., "Remittances, Financial Development and Growth. Journal of Development Economics, vol. 90, no.1, pp. 144 $-152,2009$.

[26] Gustafsson, B. and Makonnen, N., "Poverty and remittances in Lesotho", Journal of African Economies, vol. 2, np. 1, pp. 49-73, 1993.

[27] Hanson, J.L., Hair, N., Shen, D.G., Shi, F., Gilmore, J.H., Wolfe, B.L. Pollak, S.D., "Family poverty affects the rate of human infant braingrowth. PLoS One, vol. 8, no. 12, pp.1-9, 2013.

[28] Hassan, O. "The Impact of Economic Growth rate of GDP on Poverty Reduction in Nigeria", 2012.

[29] Hildebrandt, N. and McKenzie, D., "The effects of migration on the child health in Mexico", Economia, vol. 6, no. 1, pp. 257-89, 2005.

[30] Hoti E. "Remittances and Poverty in Albania", Nationalekonomiska Institutionen Vid Lunds Universitet Minor Field Study Series, vol. 192, April, 2009.

[31] Hull, K. "Understanding the relationship between economic growth, employment and poverty reduction, in Promoting pro-poor growth: Employment", OECD, 2009.

[32] Ijaiya, G. T., \& et, a. (2011). Economic Growth And Poverty Reduction In Nigeria", International Journal of Business and Social Science, vol.2. no.15, pp. 147-154, 2011

[33] Im, K.S., Pesaran, M.H., Shin, Y., "Testing for Unit Roots in Heterogeneous Panels", Journal of Econometrics, vol.115, pp. 53-74, 2003.

[34] International Monetary Fund, "World Economic Outlook", International Monetary Fund, Washington DC, 2005

[35] John B. T. "Remittance Corridors and Economic Development: A Progress Report on a Bush Administration Initiative", Under Secretary of Treasury for International Affairs, Remarks Presented at the Payments in the Americas Conference, Federal Reserve Bank of Atlanta, 2004.

[36] Jordan Central Bank, annual statistical data, various years.

[37] Jordan Strategies Forum, Jordanian Expatriate Survey, 2018.

[38] Katsushi Imai \& Raghav Gaiha \& Abdilahi Ali \& Nidhi Kaicker, "Remittances, Growth and Poverty: New Evidence from Asian 
Countries," The School of Economics Discussion Paper Series 1125 Economics, The University of Manchester, UK. 2011.

[39] Kwasi, A. (2010) "Growth, inequality and poverty reduction in developing countries: recent global evidence", Background Paper for the Global Development Outlook 2010 Shifting Wealth: Implications for Development, OECD. [Online]. Available http://www.oecd.org/dev/pgd/44773119.pdf.

[40] Leon-Ledesma, Miguel and M. Piracha, "International Migration and the Role of Remittances in Eastern Europe", International Migration, vol. 42, pp. 65-83, 2004.

[41] Levy, V. "Aid and Economic Growth in the Sub-Saharan: Africa: The recent experience", European Economic Review, vol. 32, pp. 1777 1795, 1987.

[42] Li, H., and Zou, H.-f, "Income Inequality is not Harmful for Growth: Theory and Evidence", Review of Development Economics, vol.2, pp 318-334, 1998.

[43] Lopez, H., Molina, L., Bussolo. M. (2007), "Remittances and the real exchange rate". [Online]. Available https://openknowledge.worldbank.org.

[44] Lucas, Robert E. B. "International Migration and Economic Development: Lessons from Low-Income Countries. London:”, dward Elgar Publishing 2005.

[45] Martin F. S. "Remittance Flows and Impact speech given at "Remittances as a Development Tool: A Regional Conference" organized by the Multi-lateral Investment Fund, Inter-American Development Bank, 2001.

[46] Nakabashi, L. "Poverty and economic development: Evidence for the Brazilian states", EconomiA, vol. 19, pp. 445-458, 2018.

[47] Nsour, I., and Malkawi, E. “ The Impact of World Price Changes of Oil on Economic Growth In Jordan : Econometric Study for the Period 2008 - 2019" , EPRA International Journal of Economic and Business Review, vol.7, no. 10 , pp. 32-39, 2019.

[48] Nwaogu, U.G., and Ryan, M.J. "FDI, foreign aid, remittance and economic growth in developing countries", Review of Development Economics, vol. 19 , no. 1, pp. 100-115, 2015.

[49] Nyamongoa, E.M., Misatib, R.N., Kipyegonb, L., Ndirangua, L. "Remittances, financial development and economic growth in Africa", Journal of Economics and Business, vol. 64, pp. 240- 260, 2012.

[50] Nyeadi, J.D., and Atiga, O. "Remittances and economic growth: Empirical evidence from Ghana", European Journal of Business and Management, vol. 6, no. 25, pp. 142-149, 2014.

[51] Pant, B. "Mobilizing Remittances for Productive Use: A Policyoriented Approach", NRB Working Paper no. 04/2008, Nepal Rastra Bank, Research Department, 2008.

[52] Partridge, M.D. "Is Inequality Harmful for Growth? Comment?" American Economic Review, vol. 87, no. 5, pp. 1019-1032, 1997.

[53] Partridge, M.D. "Does Income Distribution Affect U.S. State Economic Growth?", Journal of Regional Science, vol. 45, no. 2, pp. 363-394, 2005.

[54] Pesaran, M. H. "A simple panel unit root test in the presence of crosssection dependence", Journal of Applied Econometrics, vol. 22, pp. 265-312, 2007.

[55] Puri, S and T. Ritzema, "Migrant Worker Remittances, Micro Finance and the Informal Economy: Prospects and Issues", ILO Social Finance Unit, Working Paper, no. 21, Geneva, 1999.

[56] Ramirez, M.D. "Do Financial and Institutional Variables Enhance the Impact of Remittances on Economic Growth in Latin America and the Caribbean? A Panel Cointegration Analysis “, International Advances in Economic Research, vol. 19, pp. 273-288, 2012.

[57] Rapoport, Hillel and Frederic Docquier, "The Economics of Migrants' Remittances, 1135-1199 in S.C. Kolm and J.M. Ythier (eds.) Handbook of the Economics of Giving, Altruism and Reciprocity: Volume 2, North-Holland: Amsterdam, 2006.

[58] Ravallion, M. "Why Don't We See Poverty Convergence?" American Economic Review, vol. 102, no. 1, pp. 504-23, 2012.

[59] Sinding, S.W. "Population, poverty and economic development", Philos. Trans. R. Soc., vol. 364, pp. 3023-3030, 2009.

[60] Taylor,J. Edwar, Jorge Mora and Richard Adams, "Remittances, inequality and Poverty: Evidence from Rural Mexico." Unpublished Manuscript. University of California, Davis, CA, USA, 2005.

[61] Ullah Khan, M. Rehman, S., and Abdul Rehman, C. "Education and Income Inequality in Pakistan", Academy of Business \& Scientific Research, Management and Administrative Sciences Review, vol. 4, no. 1, pp. 134-145,2015.

[62] Uruçi, E. and Gedeshi, I. "Remittances management in Albania", Working Papers, no. 5. Rome: Centro Studi di PoliticaInternazionale, 2013.

[63] World Bank (2015), Personal remittances, received (\% of GDP). [Online]. Available http://data.worldbank.org.

[64] World Bank, annual statistical data, various numbers.
[65] Yang, D. "Financing constraints, economic shocks, and international labor migration: Understanding the departure and return of Philippine overseas workers", Harvard University, dissertation chapter, 2003

[66] Yassen .H "The Positive and Negative Impact of Remittances on Economic Growth in MENA Countries", The Journal of International Management Studies, vol. 7, no. 1, 2012.

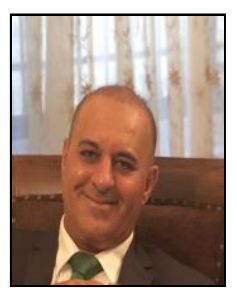

Prof Iyad A. Al-Nsour earned his undergraduate and postgraduate degrees from school of Economics at University of Jordan, Jordan. He continued his study at AAU, School of Marketing, Jordan in 2007 to get the first PhD in marketing, and he get the Second $\mathrm{PhD}$ in Economics from $\mathrm{Al}$ Madinah International University, Malaysia in 2016. Nowadays, he is a PhD Student in The Digital Marketing School at Management and Science University, Malaysia. Before that he earned the post doctorate degree in social responsibility.

Prof. Iyad Al-Nsour is currently a full professor of marketing communication at the school of advertising and marketing communication and faculty member at Media and communication in $\mathrm{Al}$ Imam Muhammad Bin Saud Islamic University.

$\mathrm{He}$ is a Jordanian and working in Saudi Arabia, and he has 16 published books in economic and marketing fields as well as 34 published articles in highly recognized national and international journals.

Prof Iyad A. Al-Nsour is from the best researchers in marketing and Economics, and his research area group includes marketing strategy, consumer behavior, marketing communication, macroeconomic policies, digital marketing and health care tourism. 